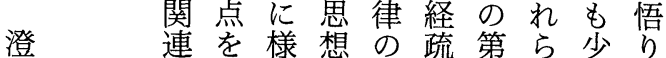

観一にあ々にこ四はなの表

の、つおおな関とお祖集く境的は

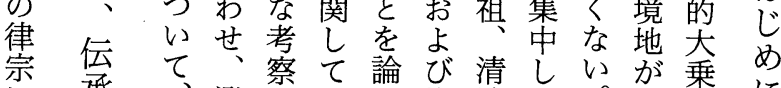

に承、澄がは祭複涼て。開烡に

おの若観な、、注澄戒梵隅典

け系芉のさ唐独で観律梵さ行さ

る系譜 考律て代特あ彼特品れる

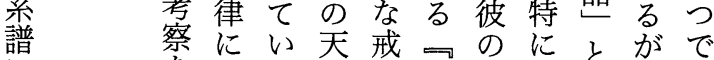

にを関る台律演穴とと市

つ加すが宗の義華乗離そる

い爷る、思鈔厳戒垢の』

る 観本禅想些経律品中華

は、も点稿宗を管経律品に噉

宋 でお澄の開で注説な゙戒経

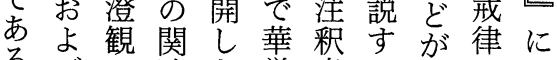
る。゙の連た㛜書る。ぞには、

国律つ澄立あ中代連仏

律思い観場る国表すの

宗想てのかっ華でる深

とにす華ら華跾、教淵

の焦で厳戒㛜宗こ説な

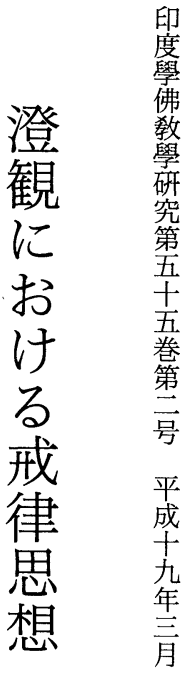

だ澄律受師部まて、っ ど澄り弟と涼歳

と観宗けに律ず、察思観澄子、゙山に

いはのた関を乾各柰想怔観、首志し

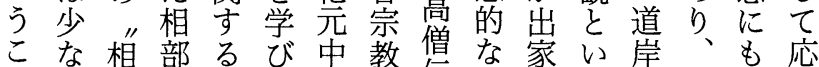

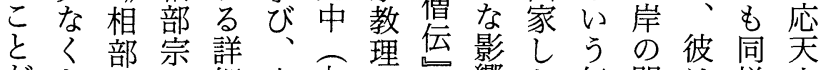

がと宗の細本七理に響た伝門は様山

言も“、律な州吾研にををば授下律の筫

え”‘師記量八究よ及加ので宗記㷊

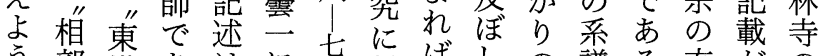

う。部塔あはに声従ばしの譜る玄がの

宗宗る僧よ旮事澄た時はこ儼見霃

"、に伝つこし澄かの容との ら 禅

と、違にてにた観は師易か弟れ師

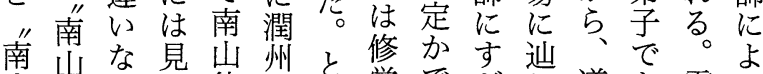

山宗いら律棲り学でぎれ道あ需る 宗“示。れ霞わ時なずよ宣る禅て

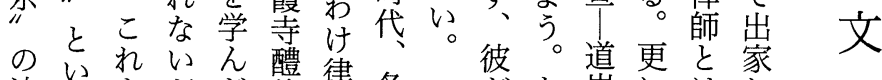

法うをがだ律宗各染た岸にはし

流亥る み法い師に宗澄だ玄寶た

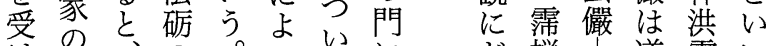

張

けう、の。ゔ禅!道需い

継う古国を醴て相は方 
てて二曇立、でら道た発砥穼をか強観をて覚

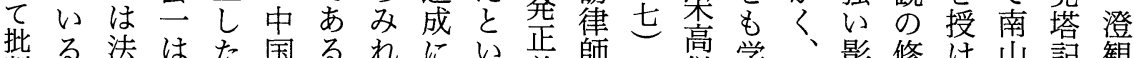
澄判る。法はた国るれにい義師長僧学、影修け山記観

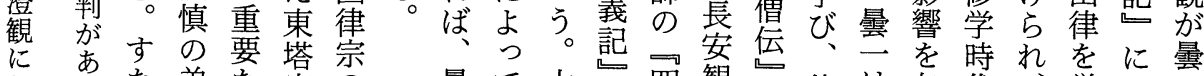
おるな弟な宗の け尔子位で至 るをちの置あ家

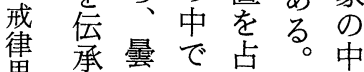

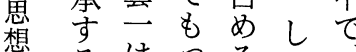

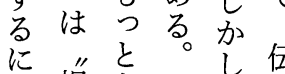

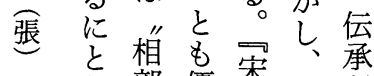

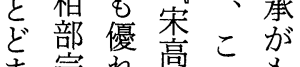
宗狱高のも 奌“炎存短々 東南考治窟短

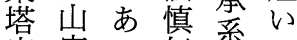
宗宗口伝稉の 律“た”譜は

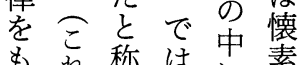

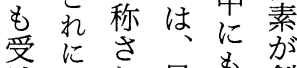
讨对藏导創

もの開もて

ま法宗文立 中 つ砺記字て 国 たの袁ら律 くのは現れ宗 同四自的た。 じ分ら律の こ疏釈同ら法 ろ先を一にい がを॥も、ず 多批新の三れ く、判 疏 が宗も 师たと多京四 疏がし例て分 のそ川えも先 文の旧ば、に 章文疏、実対

六を章”懐際す 六そので素にる の構あのは注 ま成る 西 疏 まもと四容に 転表こ分的よ

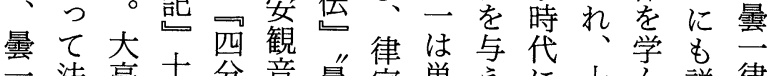

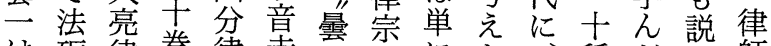
は砥律巻律寺空尔にた、種だか師 南の師を疏の伝兰南人崇量後的に 山法は著厄大”家山物誓ててよ 律を満しと亮にを律でと妾律いっ よ受意、道律ょ全のあ彼立蔵るて

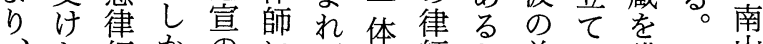

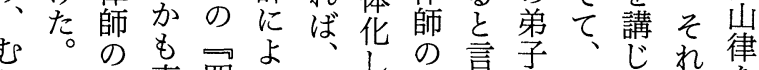

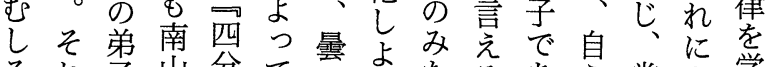

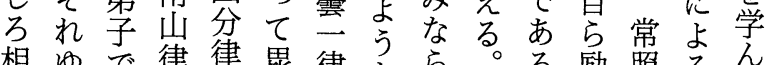
相的で律律毘律々占。る励照るん

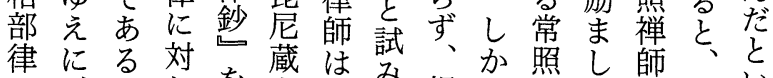

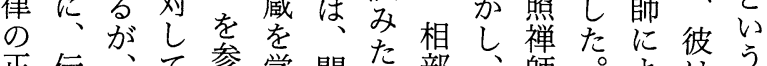

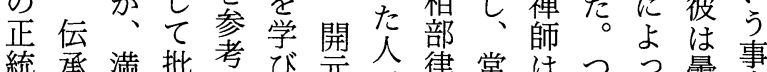

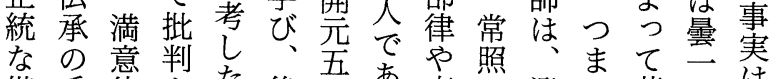

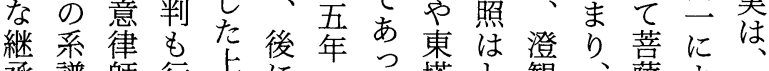

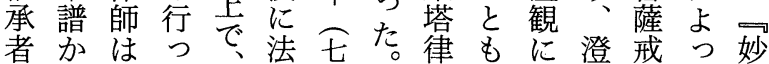

あ受れ網経に更桖継 るける経菩対更道䁲法こ律い

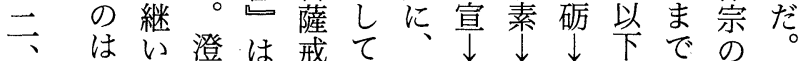
戒臭だ。観中体注華道のに法 体然。は国疏䊅厳道法成通検承観 観なし法撰些を宗岸慎】り討系は

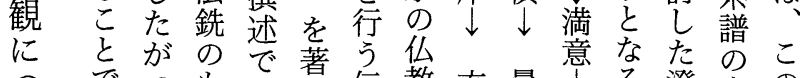

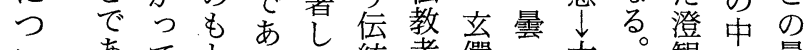

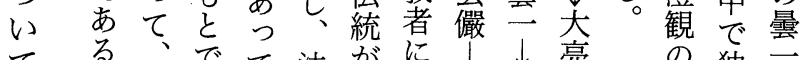

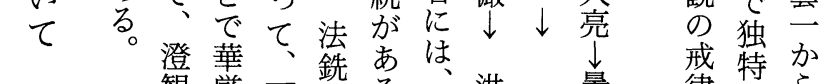

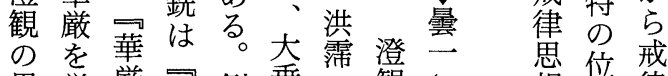
思学箃梵例乗 $\rightarrow$ 観 $\leftarrow$ 想置律

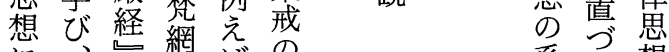
治系網ば想 梵直と䖻唐経典譜に学 網炎関を法を特整变ん゙ 経洼連㿥臓特 の名な教梵図言该

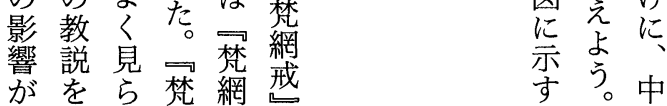




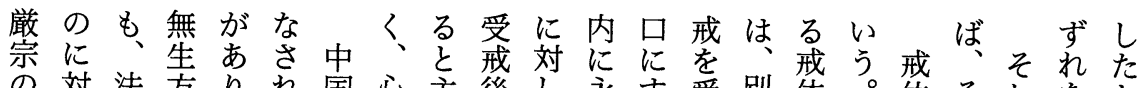

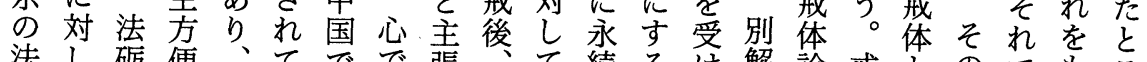

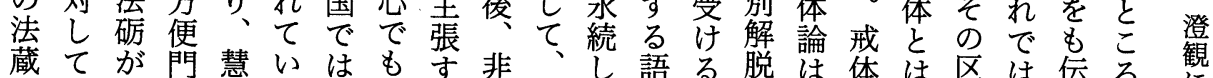

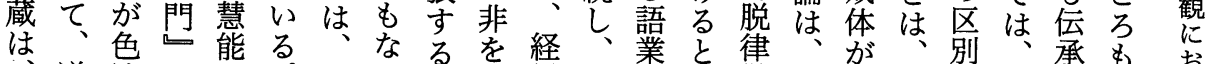

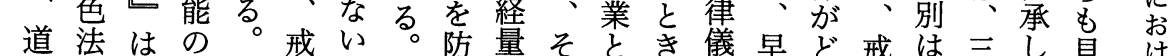

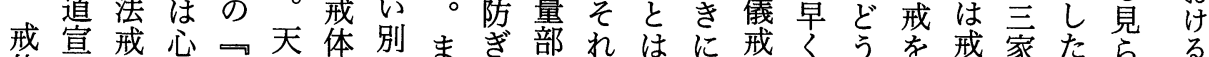
体は体法六台ののた墨はが、、、はもい受体と律れ戒 に心説戒祖智問も文戒防眼師無小うけには師る律 つ法を体壇顗題の成止の非にを表乗もる対一がる。㭷 い戒唱説経にはと成め奉止見礼色のの時す体登そ想

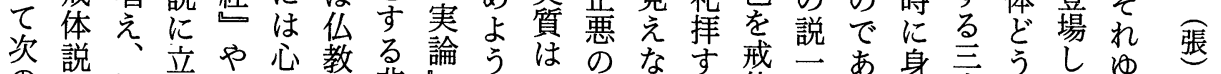

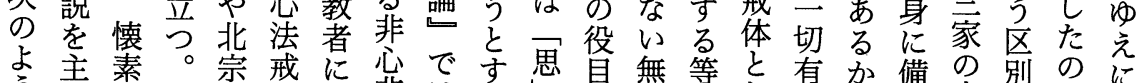
う張が四禅体よ非はる表のし部にわ立さでに に言戒分の説つ色説そ用で果色身てにつる場れあ最 言る体律思々て説そ心市たと業い展いるのるる。二

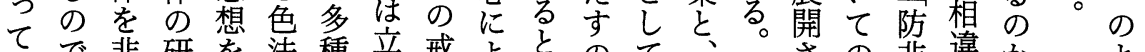

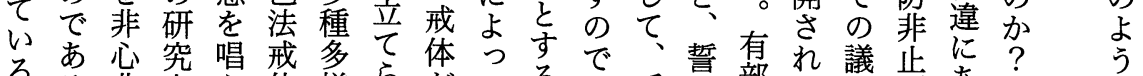

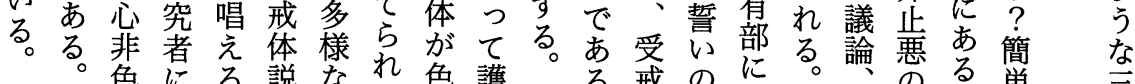

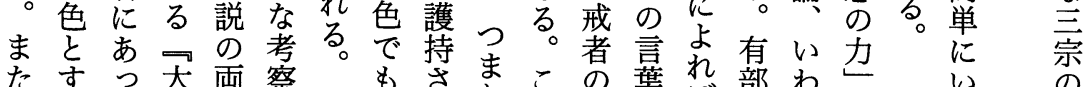

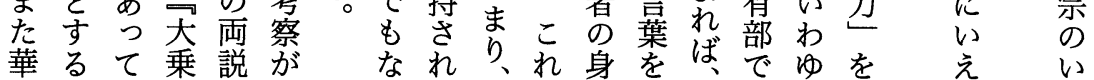

善を澄

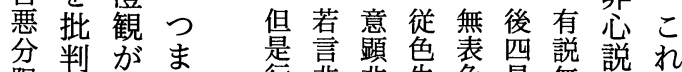

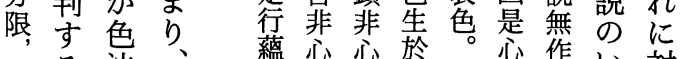

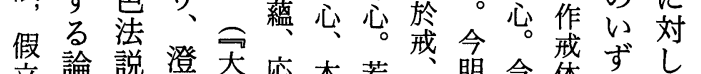

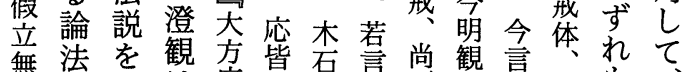

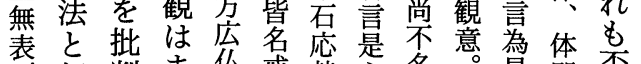

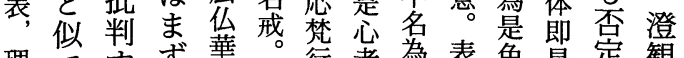
理てすず華。行者桷表色是定観 亦いる戒䈣 無る論体䖻 違る詓の起

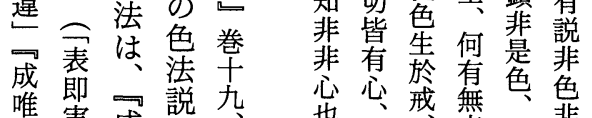
唯実成説九杂戴無色菲

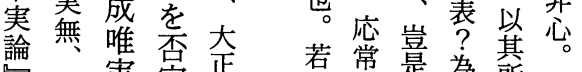
卷無実定正 巻無論宗吾 大真有こ六 企然部の盲 三, 隹色占 四願法な 是一従堂顕有。荋 韭皆色何翡説 言真显為所五

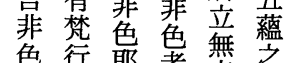

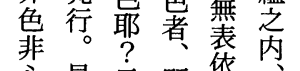
芯是言知壯表初 行薙披是韭生初 者也諳学表脃
る。法なて

で法あつ色㫇初

なでる。故思離

いなさ、云而心

。方戒韭立者

要がに体、也立謂

る思戒質梵。擎真

に種体礙網思戒

にはで経種性

法お思も咅為非

蔵い種な硪体質

はてにく椓礙

関载仮ょ縁藘整圣

連を色て急卷青總

非の成も二、等

七色姿与な大色故

戒韭各立い企 也云

体心現つの西於悲六

色卞るでで 、罟怘二

説るす非六種

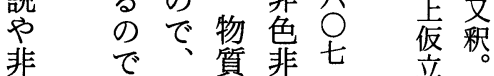

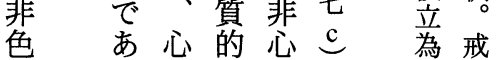




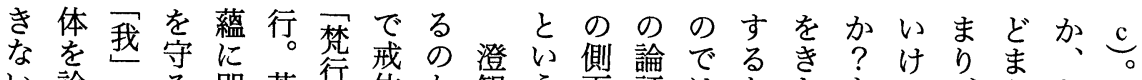

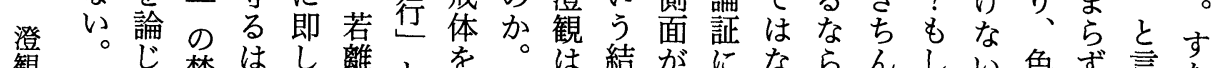

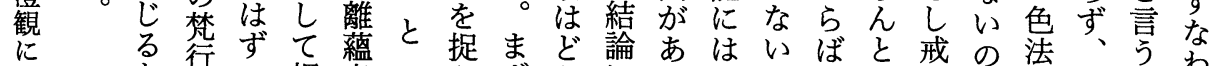

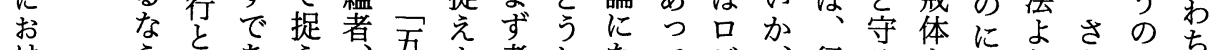

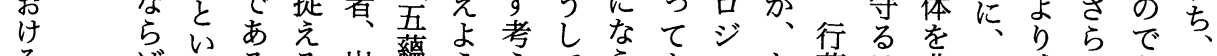

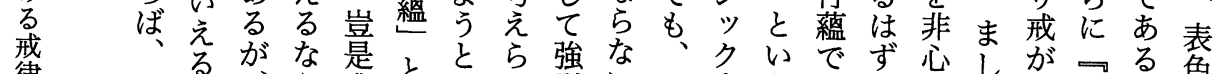

榃

想

唇

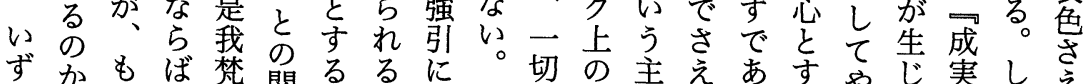
ずかもば梵関るるに

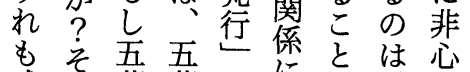

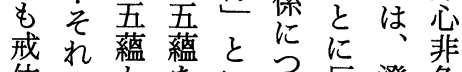

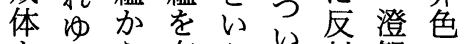
をえら有うて対観の 正に離す。て、すは戒 し、机るつる五体 く五るもま若た繿説 理藴なのり即めとを 解とらは、藴でい否 す関ばいも者あう定 る連ずし有るカ こ付どれ梵有。テよ とけうも行螕澄ゴう がてし梵は皆観りと で戒て行五梵は小卞

切の主えあすや完し完 の問張ある。る非る論か空 非題でれ。な非け諞し乑 心があばもら色れのの、法 のある、しば法ど非澄る 存る。い韭名名色観 の 在。しず色杏名、悲はに が例かれ韭石づ戒心色心 いえしも心のけ体説法ま ずばな戒のよるをを説し れ、がと戒うこ色もをて も戒ら名体なと法否否や 戒体、づを非がと定定無 体は澄け行心で名守专表 で非観ら繿法きづるる色 あ心のれでもるけ。にな る法こる摂戒のてつとの

牛うとあこ守性発は表生説

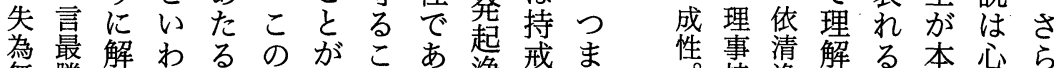
無勝秎れ離真方衣浄戒ま

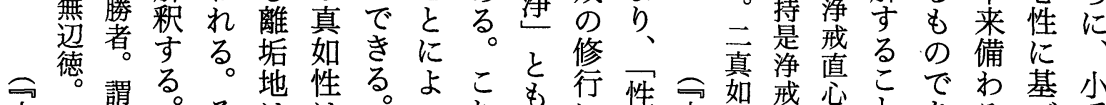

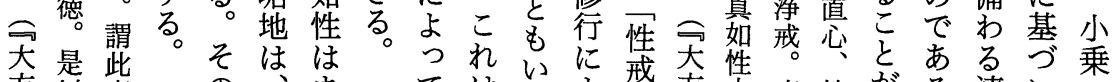

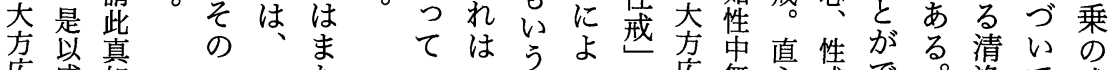

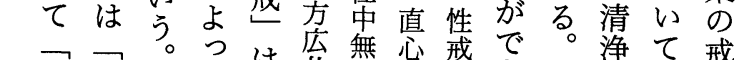

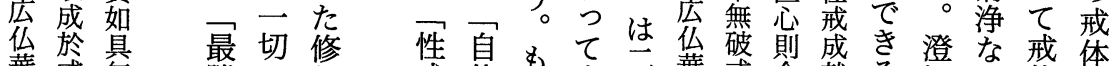

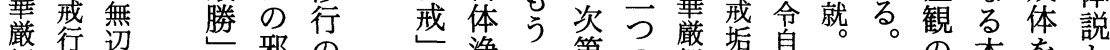

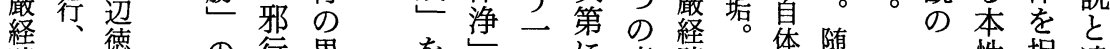
疏得德の行果をつに意䟽今体随

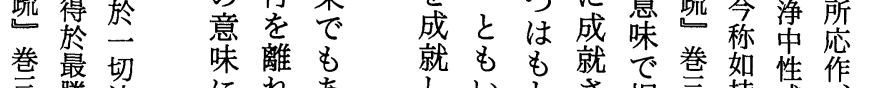

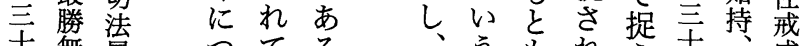

克無最

大萻勝㳅菩

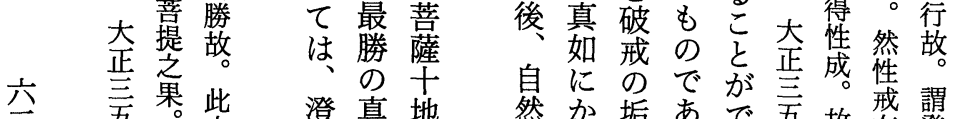

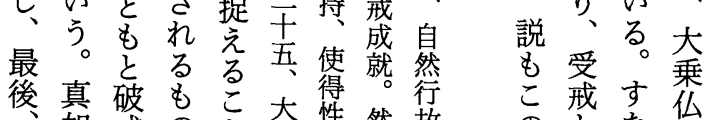
性性捉違 戒あてて のとな 教 説いわ等 然か垢あで吾故哉罦

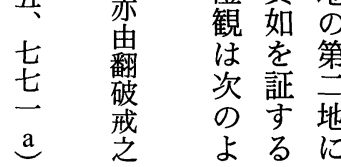
にな戒つなるきる等直起 をていこる。七就一尔

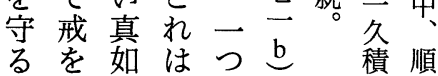

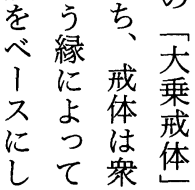


寶の大のは戒垢戒化 以別積立乗戒方る地なが大 者解経場のと戒。摄でど生乗 何脱に少経小は原盘も、戒六教 為毘は少は典垂六始生戒法た教

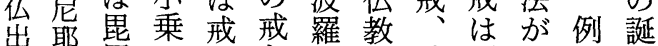

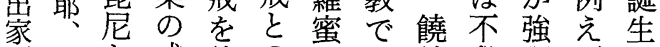
而此々戒論の成益殺調ばに

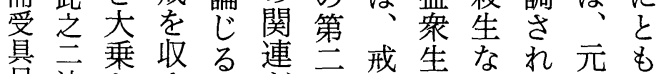
足法とめ時が位は戒どてのな 是美のよ全に皇の十ゆ五っ

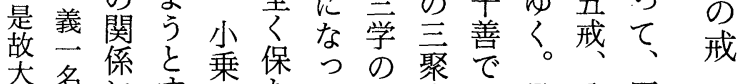

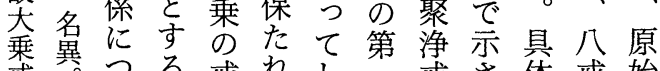
㦳異つる戒れし武さ体戒始 藴毘いのをなまででれ的の仏

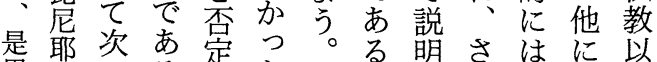

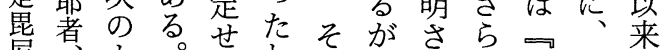
尼耶。ずわ机机十の 耶。即う例にけ年大る十皦善戒 大に常でも乗ご善経矛律

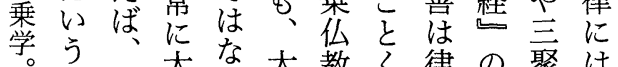
所。大乗い莗でで儀離聚変
表々の 提功

明禹前の能つ

三Lと面に果がま 三ても方述をあり、潅 小い戒らべ得る、觀 乗な体論たるの真お のいのじよこで如け 戒よてうと性る 戒少いにがこに 戒

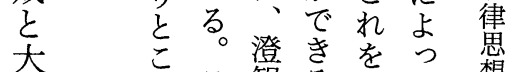
乗方こ観る。証て 想 ので真道名㦳張 あ如宣真钲 性は方失 にそ戒将を いもを戒限 て の甬行な

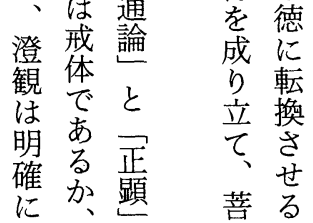

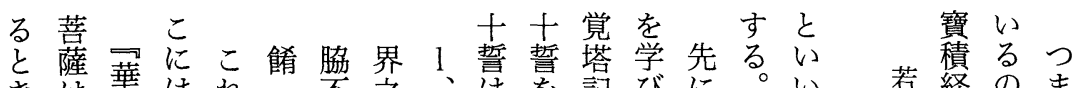
きは華はれ暨之、はを記びに。い若経のま

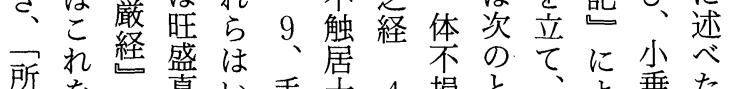

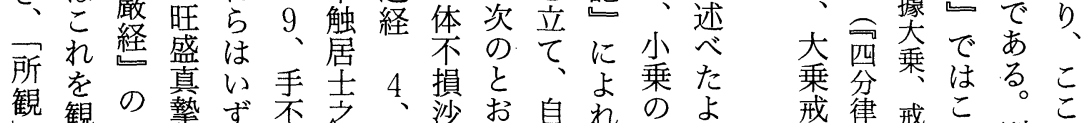

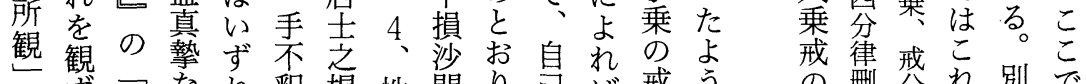

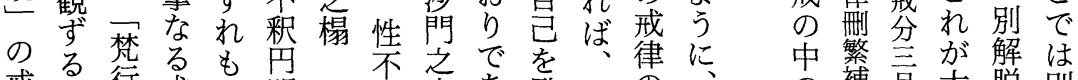
待るも円不之でを律に、中繁言が解は

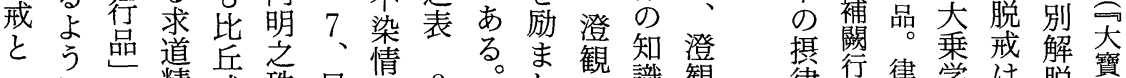

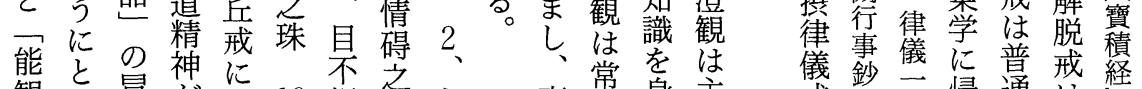

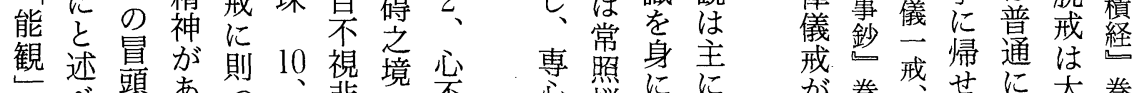

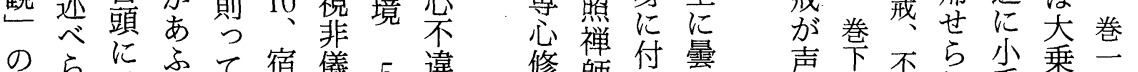

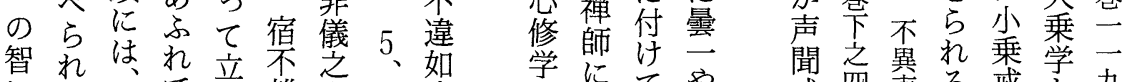

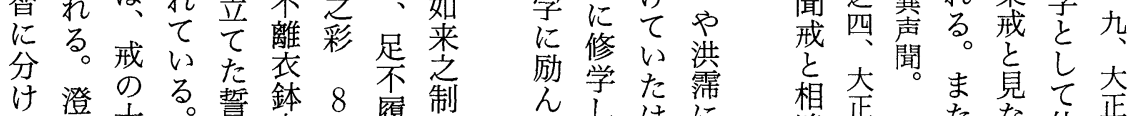
け澄のる。誓鉢8、履制ん学た霜

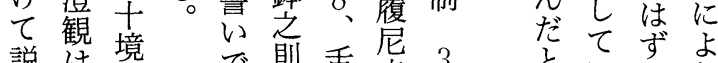

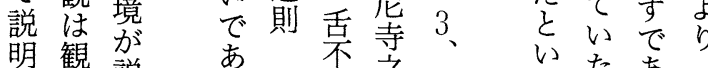

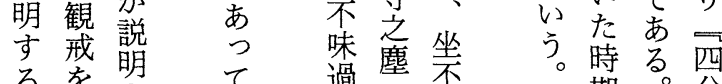

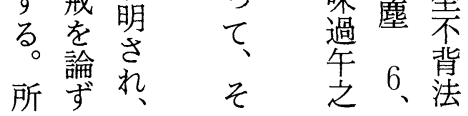

こ期军分律

乙o

w

空罯

の以妙惩張
違苜

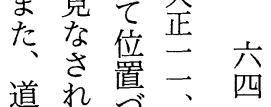
宣名讨九 星务诘杂 天热韋 


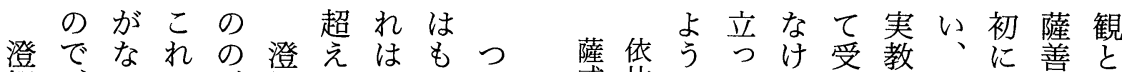
観、いに、観たあつまっ㦳比にてれ戒笅小前戒し

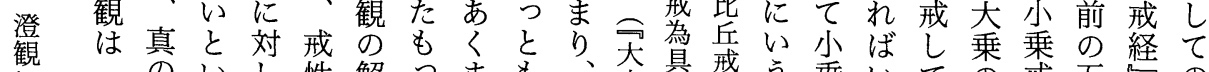

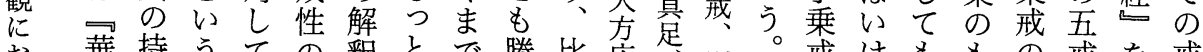
お華持うての稀とで勝比広走則

け㛜戒認、空にも方れ兵仏則至

る経で識菩をよ勝便た戒華能戒

戒告あに薩まれれに戒を㛜岳十

律のる基は阿ばたすで五経戒戒

思阿と那い゙、証—もぎあ戒随亦八

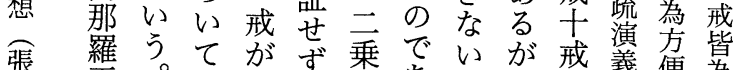

張維。㦳縁す、乗でいが戒義便為

例 受よ戒戒るな莘戒鈔超方便

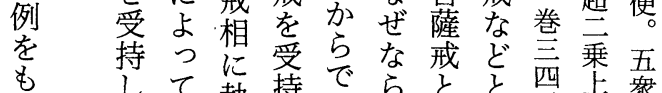

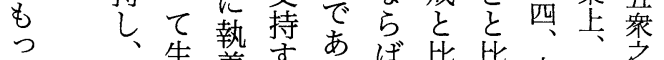

こ 戒 生着するる。比比大為最

れ 相る るるこ

を執の恐等 薩るなれ六法最

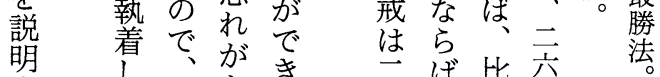

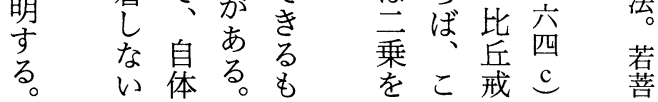

戒けももの戒を戒

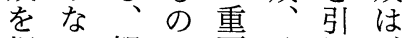

捉い観で要八用

え。法あ性戒し大

てつをるをを乗

いま修。強十菩戒

るり、すそ調戒薩と

彼澄際ゆるる゙を戒小

は観にえ。を受戒

戒ははにし受けに

のあ、、かけよ通

最く大たしなうじ

勝ま乗と能けとる

法でのえ能れ思

にも法小観ばう澄

つ大を乗といな観

い乗ものしけらは

てのつ戒てなばま

立てにのい、た

次場やよ智と皆口

のにらつはい最菩

のにさ

た価仏ま隋

と值 教ざ唐

え意のま以

ば識諸な後

道仏説判仏 律

宣教を説教

は理序 が教 教

、解 列 提 団 判

行 基华唱 の

事基す本る れ 立

鈔立もる の

場 の に 条

やをだ至件

端计圭と

戒的でた它

疏示なな

六な岁くるきが

ぞのそ、重

著ざ の 教 要

の市教はさ

中る。者単れ、
る 空 観と 那杖生 殺さ阿 ではい軽生別此羅と戒生な那 あさい苦善方有梨刀は戒い羅

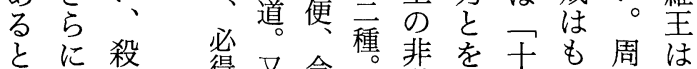

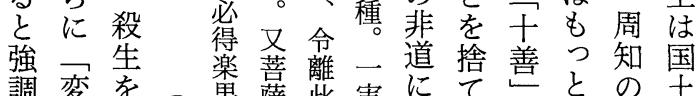
調変を菓薩喓実に行つる

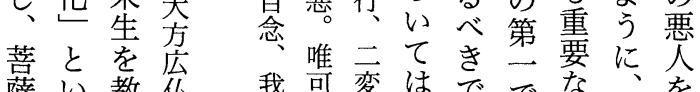
薩い教仏我可変は、ででな、少 のう化華行断华澄ああ戒小教

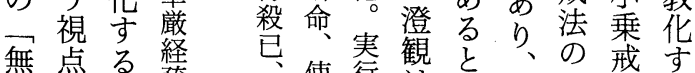
碍妿方㧧必其者は言菩二ににる

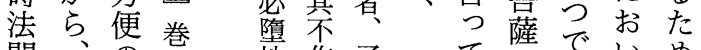
門、の吾地作了莎ででめ

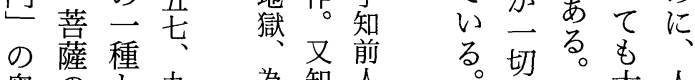
奥の厹為知人前学艺人 深諸捉至彼前窐定殺華乗を

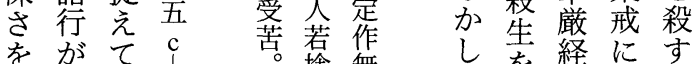

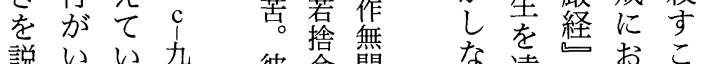
説いい九彼命間杂遠筀扢こ

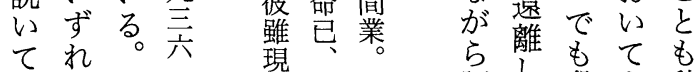
いも澄 


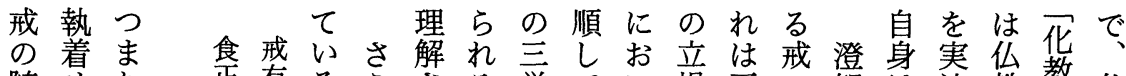
随せり歨有るらさる学てい場五の観は法教教仏 相ず、命者。に㧈。は武て古種捉は觀は宗の教澄 はに戒是者、、っ互波はらの智自交律仙を教

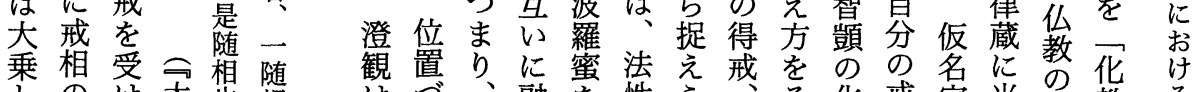

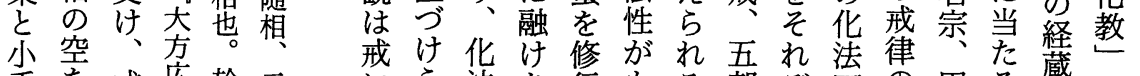
乗を戒広於二にら法あ行もる部ぞ四の円る蔵飞律 に証を众修離随れ四っすとの毘れ教思教。敦思

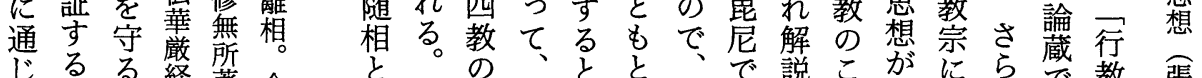

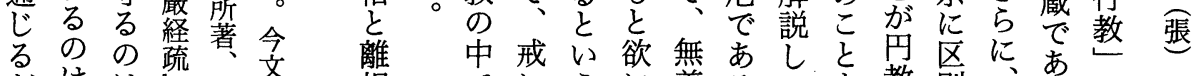
がはは起則䝺相でにうに善るてを教別にあ

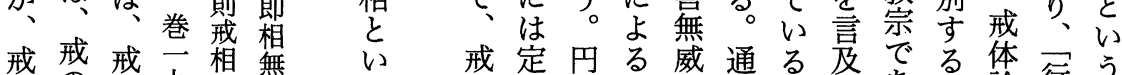

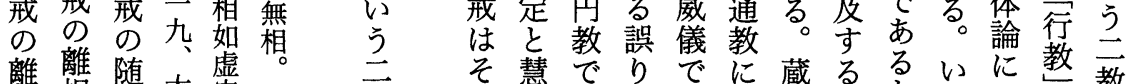
離相相昰營依擅慧でりでに蔵るるいに教教

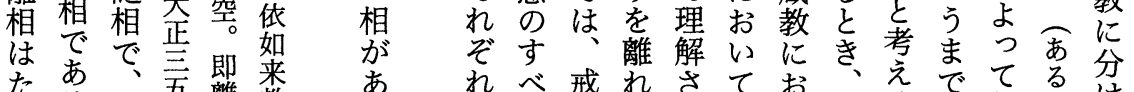

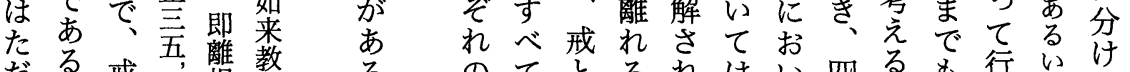

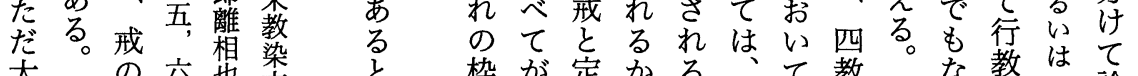

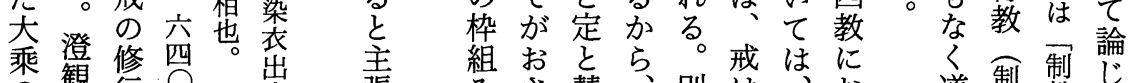

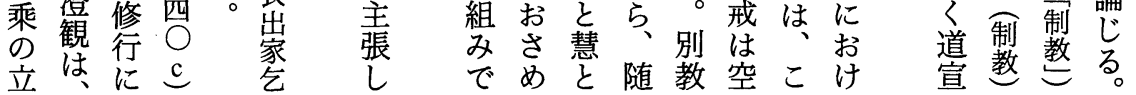

人 に律しよ基体非お南

キ 到観てう本を色い山史

）達に表 $\varepsilon$ 的説説 $\tau$ 律伝

ワ专お琞高な明を重宗に

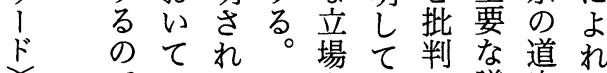

澄あでてこ華いのし議宣ば

観る。算るよ乗。がと戒澄

戒品引のま律 観

律教しな精た、る思は のた立神澄性 戒想修 戒が場に観戒体の学 がつは据は説に影期 最て澄充小をつ響に 高当観、乗展いを主 な然の小㦳開て受主 中
国
氐
学
县
謷

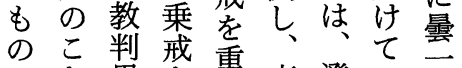
でと思を重真澄いゃ あな想々案如観る。洪 るが密中筧性は戒需

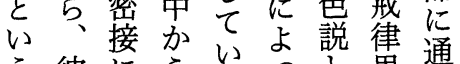
う彼にらううと思通 結戒連踅が戒热想で

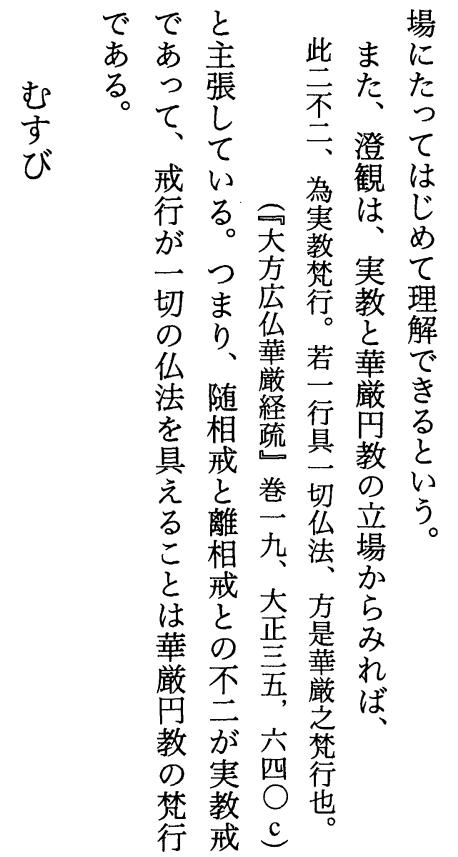


enlightenment is seen as realised by means of both impressions from learning (聞熏習) and undefiled seeds as the natural outflowing of the dharmadhātu (法界). This paper will examine whether or not the 'ConsciousnessOnly' doctrine of Mind and Enlightenment remain consistant with Buddhism's foundational conception of impermanence.

\section{The Influence of Huayan Thought on the Shi moheyan lun zanxuan shu}

YOSHIKAWA Taichirō

Fawu's Shi moheyan lun zanxuan shu (Zanxuan shu) is a commentary on the Shi moheyan lun and, with Zhifu's Shi moheyan lun tongxuan chao, occupies an important position as a work showing the high level of Liao Buddhism. But, in spite of its importance, there are extremely few studies about the Zanxuan shu.

This paper aims to clarify the concrete content of the Zanxuan shu and examines vol.1,2 concerning the influence of Huayan thought. This study is a starting point toward a general elucidation of Liao Buddhism.

\section{Chengguan's Vinaya Thought}

ZHANG Wen-liang

According to his biography, Chengguan (澄观) studied Nanshan (南山) Vinaya mostly under Tanyi (县一). According to Tanyi's biography, however, the Vinaya school ideas inherited by him are not confined to Nanshan Vina$y a$ alone; they are related to that of the Xiangbu (相部) and Dongtai (东塔) $\mathrm{Vi}$ nayas as well. Thus, the lineage of such inheritance suggests that Chengguan's Vinaya thought must have received their influence at the same time from all three branches of Chinese Vinaya School, namely Xiangbu, Dongtai and Nanshan. Moreover, as Chengguan studied the Avatamsaka sütra under Faxian (法銑) during that period of time, he must have also received influence from the Brahmajāla-sütra. While denying the two theories which explain the essence of síla in terms of a rüpa-dharma and in terms of neither citta nor rūpa respectively, Chengguan held the theory of prakrti-síla (i.e. silla in terms of nature or prakrti). This theory is further divided into two kinds, 
namely "purity of arising" and "purity of essence". They refer to obtaining the nature of Suchness (bhüta-tathatā), síla-caryā, and bodhi-phala. As far as the Hināyāna and Mahāyāna Vinayas are concerned, Chengguan did not deny the Hināyāna Vinaya, but he explained it according to Mahāyāna perspectives. For instance, he thought that although the two yānas can also observe silla, they may become attached to the characteristics/forms of silla, as they have not realized the emptiness of silla. Mahāyāna bodhisattva-s are on the other hand considered to be those who observe silla completely/ truly, as they have realized the emptiness of silla and they are not attached to the characteristics/forms of sila. As far as classification of the Teaching and silla are concerned, receiving ordination and observing silla which refer to the anulakșaṇa of sìla (戒之随相) pertain to both Mahāyāna and Hināyāna. Realization of the emptiness of characteristics/forms of silla which refers to the vilakșaṇa of silla (戒之离相) pertains to Mahāyāna only. The síla with form (anulaksana) and without form (vilaksana) are not two different things; the nonduality of the two silla is called síla of the real teaching; while the activity of silla being endowed with all Buddha-dharmas is called brahma-carya of the perfect Huayan teachings.

\section{Nanyue Huisi's Sudden Enlightment Thought}

Tsuruta Daigo

In the Meaning of the Course of Ease and Bliss of the Lotus Sūtra (法華経 安楽行義), Huisi teaches sudden enlightenment (頓覚) such that the Bodhisattva, with a single resolution (一心) and a single course of practice (一学) may attain the many diverse fruits of Buddhahood, by which is meant the infinite diversity of the Buddha's skilful teachings given for the benefit of sentient beings. Huisi's basis for this is the Sūtra of Immeasurable Meanings (無量義 経), in which it is explained that the infinite diversity of teachings are produced from the Single Dharma (一法), i.e., the Ultimate Reality (実相). This is the meaning of sudden enlightenment. Both 'a single course of practice' (一学) and the 'Single Dharma' (一法) are tantamount to the 'Single Vehicle' (一乗). Therefore, both Huisi and the Sütra agree that the infinite diversity of teachings are produced from the 'Single Vehicle' (一乗). Huisi advises Bodhi- 